UDC 616.155.394.5+616-097/-053.2-036.17

\title{
CHANGES IN THE EXPOSURE OF CD11b ON THE SURFACE OF GRANULOCYTES, AFTER ACTIVATION OF TOLL-LIKE RECEPTORS IN CHILDREN WITH RECURRENT INFECTIONS
}

\author{
D. V. Osypchuk', O. V. Rabosh ${ }^{2}$ \\ ${ }^{1}$ Institute of Pediatrics, Obstetrics and Gynecology NAMS of Ukraine \\ 8, Platon Mayboroda St., Kyiv 04050, Ukraine \\ e-mail: dariia_osypchuk@ukr.net
}

${ }^{2}$ Kyiv City Children's Center of Clinical Immunology, 30, Bogatyrska St., Kyiv 04209, Ukraine

The effect of activation of Toll-like receptors (TLR) on presentation of CD11b adhesion molecule at the granulocytes surface in children of different age with recurrent infections was investigated. Stimulation of TLR2, TLR4, TLR7/TLR8 by agonists led to a significant increase of the content of integrin CD11b in the granulocytes cytoplasmic membrane.

The amount of CD11b after stimulation of TLR7/8, was lower in groups of children with recurrent infections, compared with matched-age control groups. The amount of integrin CD11b on granulocytes surface, following activation TLR, did not differ statistically between the studied and control groups of different ages.

In addition, we analyzed the ligand-dependent content of CD11b in granulocytes surface membrane of each group. Thus, in the control groups, amount of CD11b did not differ statistically after incubation of blood cells with agonists of TLRs (LPS, R848 and PGN). Conversely, in groups of children with recurrent infections, levels of induced CD11b production were statistically distinctive depends on ligands and the lowest content of CD11b was obtained after incubation of blood cells with R848.

Thus, exploring the influence of TLR activation on the amount of integrin CD11b on the granulocyte's surface showed that the growth rate of CD11b after activation, independent of age. Groups of children with recurrent infections showed significantly lower amount of CD11b on granulocytes after activation of TLR7/8, compared with agematched control groups. Such a decreased presentation of adhesion molecules at granulocyte's surface in response to TLR7/8 stimulation by R848 can lead to preventing migration of granulocytes to the infection site and promote an increased sensitivity to viral infections and bacterial complications.

Keywords: Toll-like receptors (TLR), granulocytes, CD11b adhesion molecular.

\section{INTRODUCTION}

Granulocytes form the first and most prominent line of cellular defense against invading microorganisms. Active recruitment of granulocytes to the sites of infection is 
fundamentally important for the innate immune system. Phagocytes binds to and ingest microorganisms by a process known as phagocytosis, which typically triggers the production of reactive oxygen species (ROS) and the fusion of cytoplasmic granules with pathogen-containing vacuoles. The combination of neutrophil and granule components is highly effective in killing most bacteria and fungi [9]. Toll-like receptors (TLRs) are type 1 transmembrane receptors that play an important role in innate immune recognition of pathogens [14]. Recognition of conserved molecular patterns of microbial cell walls by these invariant, germ line - produced receptors leads to activation of cascade of signal transduction resulting in cellular activation and cytokine releasing in both immune and nonimmune cells [5]. Human neutrophils produce most of the TLRs marked as: TLRs 1 , $2,4,5,6,7,8,9$, and 10 .

Signaling through these receptors (triggered by purified stimuli for these receptors) results in the production of interleukin-8 (IL-8), triggers the shedding of L-selectin on their surface, primes for $\mathrm{N}$-formylatedmethionine- leucine-phenylalanine peptide (fMLF)mediated superoxide production, increases the rate of phagocytosis, and decreases IL-8-induced chemotaxis. [5]. Although antiviral immunity has classically been studied in terms of the adaptive arm of the immune system, much evidence exists to suggest that early stage innate immunity plays an important role. Presence of TLR recognizing viral antigens TLR7, TLR8 and TLR9 on granulocyte's surface, indicates the active involvement of these cells into defense against viral infections. Granulocytes activation mediated by these receptors leads to the synthesis of IL-8, MMP-9, proteolytic proteins and induces the production and deposition of NETs [4, 8]. Thus, TLR and granulocytes - are the key components of innate immunity that protect against a wide spectrum of pathogens. Activation of granulocytes mediated by TLRs provides timely realization of effector functions and elimination of the pathogen. Disturbance of the functioning TLR leads to decreased functional activity of cells, which contributes to susceptibility to bacterial and viral infections $[1,10]$.

Our aim was to investigate changes in the exposure of CD11b on the surface of granulocytes, after activation of Toll-like receptors in children with recurrent infections.

\section{MATERIALS AND METHODS}

After informed consent of parents were taken, heparin-treated blood was sampling from 18 healthy control subjects and from 25 patients with recurrent respiratory infections with accompanied by bacterial complications (otitis, pneumonia, sinusitis). The healthy control subjects were divided into two groups - control group-1 ( $n=5$, median age $=2$ years) and control group $-2(n=13$, median age $=9$ years). Patients with recurrent infections were divided into two groups as well - studied group-1 ( $n=14$, median age $=1$ year and 7 months $)$ and studied group $-2(n=11$, median age $=8$ years $)$. Samples of blood in volume $100 \mu \mathrm{L}$ were incubated for 1 hour without stimulation or with TLR agonists, at $37{ }^{\circ} \mathrm{C}$ in a humidified atmosphere containing $5 \% \mathrm{CO}_{2}$. TLR agonists were added to probes in concentrations: peptidoglycan from Staphylococcus aureus, agonist for TLR2 ("Sigma Aldrich", USA), $11 \mu \mathrm{g} / \mathrm{mL}$; lipopolysaccharide (LPS) from Escherichia coli, agonist for TLR4 ("Sigma Aldrich", USA) -100 ng / mL: synthetic analogue of the single-stranded RNA - resiquimod (R848) agonist for TLR7/8 - (“Sigma Aldrich", USA) $3.3 \mu \mathrm{g} / \mathrm{ml}$ and PMA (Sigma, P-8139), $90 \mathrm{ng} / \mathrm{mL}$. After the activation of patient's blood cells, erythrocytes were lysed in FACS lysing solution ("BD Science", USA), and cells were washed in Cell Wash solution («Sigma Aldrich», USA). The contents of each tube

ISSN 1996-4536 (print) • ISSN 2311-0783 (on-line) • Біологічні Студії / Studia Biologica • 2016 • Том 10/№1 • С. 37-44 
were incubated for 15 minutes on ice with the phycoerythrin - conjugated anti-human CD11b antibodies. The samples were analyzed by flow cytometry, and the results were shown as histograms of events gated on granulocytes in an sideward scatter/ forward diagram, with the mean calculated in each case. Granulocytes were identified using their light-scattering properties. For each sample, 10000 events were recorded. CD11b amount at the granulocytes membrane surface was expressed in mean fluorescence intensity (MFI).

Data analysis. A significance of differences between the groups was calculated using Student's $t$-test. $\mathrm{P}<0.05$ was considered to be statistically significant.

\section{RESULTS AND DISCUSSION}

CD11b belongs to the integrin family and is presented on membrane surface of neutrophils, monocytes, natural killer cells, and a subset of lymphocytes [13]. Our investigation obtained that the level of spontaneous CD11b production in a studied group-1 was $182.8 \pm 76.6 \mathrm{MFI}$, and did not differ statistically compared to the control group-1 232.8 $\pm 63.9 \mathrm{MFI}$. The spontaneous amount of CD11b on granulocyte's surface in studied group-2 was $177.6 \pm 43.8 \mathrm{MFI}$, and also did not differ statistically compared to control group-2 (214.7 $\pm 100.5 \mathrm{MFI})$ (Fig. 1, 2).

Incubation with the peptidoglycan (PGN) led to a significant increase in the level of integrin CD11b on the surface of granulocytes. PGN is the major component of the cell wall of gram-positive bacteria. In vitro, PGN isolated from conventional bacterial cultures can induce secretion of proinflammatory cytokines by human monocytes, indicating that PGN may be involved in immune responses against infections by gram-positive bacteria [10]. PGN was chosen as a stimulus due to its known ability to stimulate CD11b cells through Toll-like receptor 2 [2, 3]. We have shown that the level of CD11b in control group-1 and studied group-1 was increased after PGN stimulation of blood cells (578.1 $\pm 119.0 \mathrm{MFI}$ and 573.3. $\pm 150.7 \mathrm{MFI}$, respectively, $\mathrm{P}=0.07)$ (Fig. 1). The level of CD11b in control group-2 was $573.5 \pm 181.6 \mathrm{MFI}$ and did not differ compare to studied group-2 $-624.4 \pm 132.9 \mathrm{MFI}(P=0.3)$. The data show that the activation of TLR2 by PGN lead to increased level of CD11b on the granulocyte's surface, but without statistical difference between groups.

TLR7 and TLR8 are the representatives of group of intracellular receptors that recognize single-stranded viral RNA (ssRNA) enriched by guanosine [14]. Since ssRNA are not specific component of pathogens, compartmentalization - endosomal or fagosomal - is necessary to avoid autoimmune reactions [6]. It is known that activation of TLR7 and TLR8 leads to the synthesis of cytokines IL-6, IL-8 and other proinflammatory mediators, which demonstrates the importance of these receptors in the antiviral activity of granulocytes [8, 14]. Incubation with synthetic agonist of TLR7/8 - R848, led to a less intensive magnification of amount of CD11b compared to incubation with PGN. Studied group-1 showed lower level of CD11b expression - 366.1 $\pm 90 \mathrm{MFI}$ compared to control group-1 459.2 $\pm 105.8 \mathrm{MFI}, \mathrm{P}<0.01$ (Fig. 1) as well as studied group-2 (387.8 $\pm 72.1 \mathrm{MFI})$ compared to control group-2 - 506.8 $\pm 174.0 \mathrm{MFI}, \mathrm{P}<0.05$ (Fig. 2). Both studied groups showed lower presentation of CD11b on granulocyte's surface after activation of TLR7/8 comparing with matched control groups.

As PGN, other bacterial components - lipopolysaccharide (LPS) leads to a significant increase in the CD11b expression level on the surface of granulocytes. The level of expression of CD11b in a studied group-1 was $470.3 \pm 118.1 \mathrm{MFI}$ and there was no sta-

ISSN 1996-4536 (print) • ISSN 2311-0783 (on-line) • Біологічні Студії / Studia Biologica • 2016 • Том 10/№1 • С. 37-44 


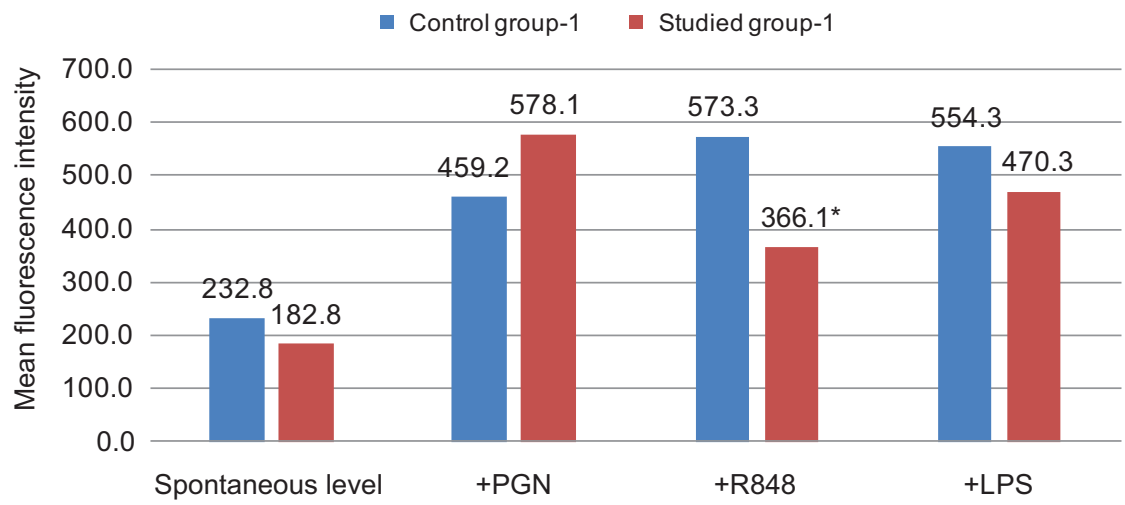

Fig. 1. Mean fluorescence intensity of CD11b adhesion molecules, bounded with phycoerythrin-conjugated anti-human CD11b antibodies on the granulocytes membrane surface in control group-1 and studied group-1 after incubation with Toll-like receptors (TLR) agonists. PGN - peptidoglycan, which activates TLR2; R848 - resiquimod, which activates TLR7/8; LPS - lipopolysaccharide, which activates TLR4; *- P $<0.01$, as compared with the control group

Рис. 1. Середня інтенсивність флуоресценції CD11b адгезивних молекул, мічених фрікоеритрин-кон'югованими моноклональними антитілами, на поверхні мембрани гранулоцитів у контрольній групі-1 і досліджуваній групі-1 після інкубації з агоністами Толл-подібних рецепторів (TLR): ПГН пептидоглікан, який активує TLR2; R848 - резиквімод, який активує TLR7/8; ЛПС - ліпополісахарид, який активує TLR4; *- P < 0,01 різниця достовірна порівняно з контролем

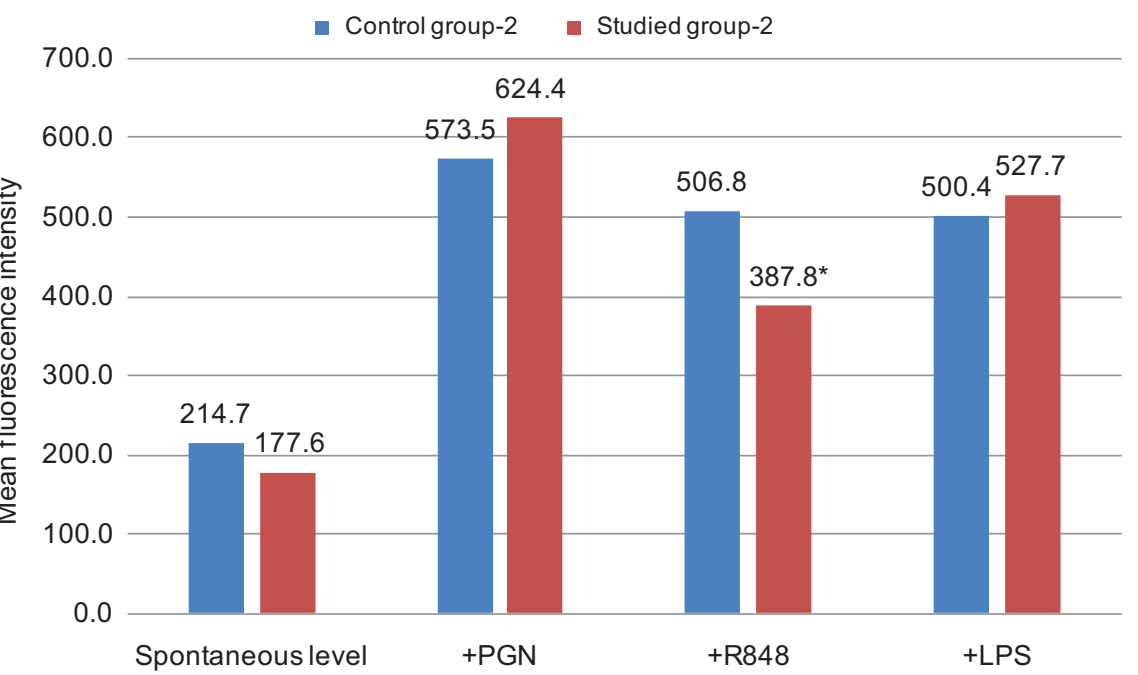

Fig. 2. Mean fluorescence intensity of CD11b adhesion molecules bounded with phycoerythrin-conjugated anti-human CD11b antibodies on the granulocytes membrane surface in control group-2 and studied group-2 after incubation with Toll-like receptors (TLR) agonists. PGN - peptidoglycan, which activates TLR2; R848 - resiquimod, which activates TLR7/8; LPS - lipopolysaccharide, which activates TLR4; *- $\mathrm{P}<0.05$, as compared with the control group

Рис. 2. Середня інтенсивність флуоресценції CD11b адгезивних молекул, мічених фрікоеритрин-кон'югованими моноклональними антитілами, на поверхні мембрани гранулоцитів у контрольній групі-2 і досліджуваній групі-2 після інкубації з агоністами Толл-подібних рецепторів (TLR): ПГН пептидоглікан, який активує TLR2; R848 - резиквімод, який активує TLR7/8; ЛПС - ліпополісахарид, який активує TLR4; *- P < 0,05 різниця достовірна порівняно з контролем 
tistically difference compared to the control group-1 - 554.3 $\pm 193.2 \mathrm{MFI} P=0.2$ (Fig. 1). The amount of CD11b after incubation of blood cells with LPS in studied group-2 (527.7 $\pm 112.8 \mathrm{MFI})$ also did not differ compare to control group-2 (500.4 $\pm 195.1 \mathrm{MFI}$, $P=0.4$ ) (Fig. 2). As data show, bacterial components - PGN and LPS lead to intense increase in the CD11b amount on granulocyte's surface, but without statistical difference between groups.

Experimental data showed that the level of induced expression of CD11b differ depending on the group and selected TLR ligands. In addition, we decided to analyze does levels of production of CD11b in each group, differ depending on the ligands. Thus, in the control group, levels of expression after incubation of blood cells with LPS, R848 and PGN did not differ statistically. Conversely, in the studied groups levels of induced CD11b expression were statistically different depends on ligands and the lowest level of amount of CD11b was after incubation of blood cells with R848 (data not shown).

To find out whether TLR activation depends on age, we compared the amount of integrin CD11b following activation of TLR between studied and control subgroups. The amount of CD11b on granulocytes after activation of TLR did not differ between studied group-1 and studied group-2. Either, the amount of integrin CD11b on granulocytes following activation of TLR did not differ between control group-1 and control group-2. Also, there was no correlation found between age and the amount of CD11b on granulocytes, after TLR activation (data not shown). Based on these data, we can suggest that this mechanism of TLR activation is independent of age.

Timely infiltration of granulocytes into inflammation sites plays a crucial role in the elimination of infection. Circulating neutrophils are rapidly recruited to sites of infection by host- and pathogen-derived components, which also prime these host cells for enhanced microbicidal activity. Reducing the presentation of adhesion molecules on granulocytes membrane surface in response to stimulation by antigens may led to impaired migration to the sites of infection and diminished pro-inflammatory response as a result.

As our data showed, that both studied groups shows lower amount of CD11b on granulocytes membrane after stimulation of TLR7 / 8 compared to the control groups. While the amount of CD11b on the granulocytes membrane after stimulation TLR4 and TLR2 did not differ statistically between studied and control groups.

Also, there was a significant difference between the levels of induced CD11b expression depending on type of TLR binding ligands in the studied groups. The lowest content of CD11b in granulocytes membrane was after stimulation TLR $7 / 8$. The content of CD11b in granulocytes membrane after stimulation of TLR did not depend on type of TLR binding ligands in the control groups. These findings demonstrate selective disturbance of TLR7/8 activation in the studied groups.

Previous study showed a decreased in the amount of adhesion molecules, including CD11b, on neutrophils surface in the peripheral blood under experimental rhinovirus infection [13]. Inhibition of a functional response of peripheral blood mononuclear cells to TLR activation was shown in the group of children with the flue [7]. These changes were transient, and restored after a certain period of time. However, a transient decreased in response to TLR agonists can create favorable conditions for bacterial complications. It was showed that $60 \%$ of patients had bacterial complications afterall [13]. Also, activated neutrophils provide signals for the activation and maturation of macrophages as well as dendritic cells. Neutrophils are also involved in regulation of T-cell immune response against various pathogens. Impaired functional activity, even transient, can

ISSN 1996-4536 (print) • ISSN 2311-0783 (on-line) • Біологічні Студії / Studia Biologica • 2016 • Том 10/№1 • C. 37-44 
lead to disruption of coordination adaptive and innate immune responses, and as a result to recurrent and severe infections

We suggest that a reduced response of granulocytes to TLR7 / 8 activation is the primary cause of increased susceptibility to viral infections. To answer this question, the following research should be directed to the assessment of effect of TLR7/8-mediated activation of granulocytes on immune system, in post-infectional time. It will help us to understand whether these changes are transient and what is the restoration time needed for normal functional activity of granulocytes.

\section{CONCLUSIONS}

1. Integrin CD11b amount on granulocytes after activation of TLR7/8 in children with recurrent infections was lower compared to healthy subjects; such reduced presentation of CD11b on granulocytes membrane surface in response to stimulation by antigens in children with recurrent infections, may led to impaired migration to the sites of infection and diminished pro-inflammatory response as a result.

2. CD11b content in the granulocytes cytoplasmic membrane after activation of TLR depends on type of TLR binding ligands in the studied groups and does not depend in the control groups.

3. Integrin CD11b amount on granulocytes, following activation TLR did not differ statistically between the groups of different ages.

1. Bouma G., Doffinger R., Patel S.Y. Impaired neutrophil migration and phagocytosis in IRAK-4 deficiency. Br. J. Haematol, 2009; 4(7): 153-6.

2. Dziarski R., Gupta D. Staphylococcus aureus Peptidoglycan Is a Toll-Like Receptor 2 Activator: a Reevaluation. Infect. Immun, 2005; 73(8): 5212-6.

3. Fong O.N., Chan K.Y., Leung K.T. Expression profile of cord blood neutrophils and dysregulation of HSPA1A and OLR1 upon challenge by bacterial peptidoglycan. J. Leukoc. Biol, 2014; 95(1): 169-78.

4. Hattermann K., Picard S., Borgeat M. et al. The Toll-like receptor 7/8-ligand resiquimod (R-848) primes human neutrophils for leukotriene B4, prostaglandin E2 and platelet-activating factor biosynthesis. FASEB J, 2007; 21(7): 1575-85.

5. Hayashi F., Means T.K., Luster A.D. Toll-like receptors stimulate human neutrophil function. Blood, 2003; 102: 2660-69.

6. Heine H. TLRs, NLRs and RLRs: Innate sensors and their impact on allergic diseases. Immunol. Lett, 2011; 30(139): 14-24.

7. Heltzer M.L., Coffin S.E., Maurer K. et al. Immune dysregulation in severe influenza. J. Leukoc. Biol, 2009; 85(6):1036-43.

8. Jenne C.N., Wong C.H., Zemp F.J. et al. Neutrophils Recruited to Sites of Infection Protect from Virus Challenge by Releasing Neutrophil Extracellular Traps. Cell. Host. Microbe, 2013; 13(2): 169-80.

9. Kobayashi S.D., Voyich J.M., Burlak C. et al. Neutrophils in the innate immune response. Arch. Immunol. Ther. Exp, 2005; 53:505-17.

10. Kumar V., Sharma A. Neutrophils: Cinderella of innate immune system. Int. Immunopharmacol, 2010; 10(11): 1325-34.

11. Ku C.L., von Bernuth H.,Picard C. et al. Selective predisposition to bacterial infections in IRAK-4-deficient children: IRAK-4-dependent TLRs are otherwise redundant in protective immunity. J. Exp. Med, 2007; 204: 2407-22. 
12. Langer M., Malykhin A., Maeda K. et al. Bacillus anthracis Peptidoglycan Stimulates an Inflammatory Response in Monocytes through the p38 Mitogen-Activated Protein Kinase Pathway. PLoSONE, 2008; 3(11): e3706.

13. Mallia P., Message S., Contoli M. et al.Neutrophil adhesion molecules in experimental rhinovirus infection in COPD. Respir. Res, 2013; 14: P. 72.

14. Medzhitov R. Toll-like receptors and innate immunity. Immunology, 2001; 1: 135-145.

15. Tang F.S., Van Ly D., Spann K. Differential neutrophil activation in viral infections: Enhanced TLR-7/8-mediated CXCL8 release in asthma. Respirology, 2016; 21(1): 172-9.

16. Springer T. A. Adhesion receptors of the immune system. Nature, 1990; 346: 425- 434.

\title{
ЗМІНИ В ЕКСПОНУВАННІ СD11b НА ПОВЕРХНІ ГРАНУЛОЦИТІВ ПІСЛЯ АКТИВАЦІЇ TOLL-ПОДІБНИХ РЕЦЕПТОРІВ У ДІТЕЙ, ЩО ЧАСТО ХВОРІЮТЬ
}

\author{
Д. В. Осипчук', О. В. Рабош' \\ 1/нститут педіатрії, акушерства і гінекології НАМН України \\ вул. Платона Майбороди, 8, Київ 04050, Україна \\ e-mail:dariia_osypchuk@ukr.net \\ ${ }^{2}$ Київський міський дитячий центр клінічної імунології ${ }^{2}$ \\ вул. Богатирська, 30, Київ 04209, Україна
}

У роботі було досліджено вплив агоністів TOLL-подібних рецепторів (TLR) на зміни експонування CD11b молекул адгезії на поверхні гранулоцитів у дітей різного віку, що часто хворіють. Стимуляція TLR2, TLR4, TLR 7/8 відповідними агоністами призводила до значного зростання загальної кількості інтегрину CD11b у цитоплазматичній мембрані гранулоцитів. Кількість CD11b після стимуляції TLR 7/8 була достовірно нижчою у групах дітей, що часто хворіють, порівняно з контрольними групами відповідного віку. Кількість інтегрину CD11b на поверхні гранулоцитів, після активації TLR не відрізнялася статистично між групами різного віку в досліджуваних і контрольних групах.

Додатково ми проаналізували ліганд-залежну кількість CD11b на мембрані гранулоцитів у досліджуваних і контрольних групах. У контрольних групах кількість CD11b не відрізнялася статистично після інкубації клітин крові з агоністами TLR (ЛПC, R848, ПГН). На противагу цьому, в групах дітей, що часто хворіють, рівні індукованої продукції CD11b відрізнялися залежно від лігандів, і найнижчу кількість CD11b спостерігали після інкубації клітин крові з R848.

Отже, дослідженням впливу активуючих чинників на кількість інтегрину CD11b на поверхні гранулоцитів доведено, що рівень приросту CD11b після активації не залежить від віку. У групах дітей, що часто хворіють, було виявлено достовірно нижчий рівень приросту CD11b на гранулоцитах після активації TLR7/8, порівняно з контрольними групами відповідного віку. Така знижена презентація молекул адгезії на поверхні гранулоцитів у відповідь на стимуляцію TLR7/8 лігандом може перешкоджати міграції цих клітин до місця інфікування, сприяти підвищеній чутливості до вірусних інфекцій і виникненню бактеріальних ускладнень.

Ключові слова: TOLL-подібні рецептори (TLR), гранулоцити, CD11b молекула адгезії. 


\title{
ИЗМЕНЕНИЯ ЭКСПОНИРОВАНИЯ СD11b НА ПОВЕРХНОСТИ ГРАНУЛОЦИТОВ ПОСЛЕ АКТИВАЦИИ ТОLL-ПОДОБНЫХ РЕЦЕПТОРОВ У ЧАСТО БОЛЕЮЩИХ ДЕТЕЙ
}

\author{
Д. В. Осипчук', О. В. Рабош'² \\ ${ }^{1}$ Институт педиатрии, акушерства и гинекологии НАМН Украины \\ ул. Платона Майбороды, 8, Киев 04050, Украина \\ e-mail: dariia_osypchuk@ukr.net \\ ${ }^{2}$ Киевский городской детский центр клинической иммунологии \\ ул. Богатырская, 30, Киев 04209, Украина
}

B работе было исследовано влияние активации TOLL-подобных рецепторов (TLR) на изменения экспонирования CD11b на поверхности гранулоцитов у часто болеющий детей разного возраста. Стимуляция TLR2, TLR4, TLR7/8 соответствующими агонистами приводила к значительному росту общего количества интегрина CD11b в цитоплазматической мембране гранулоцитов. Количество CD11b после стимуляции TLR7/8 было достоверно ниже в группах часто болеющих детей, в сравнении с контрольными группами соответствующего возраста. Количество интегрина CD11b на поверхности гранулоцитов после активации TLR не отличалось статистически между контрольными и исследуемыми группами разного возраста.

Дополнительно мы проанализировали лиганд-зависимое количество CD11b на мембране гранулоцитов в контрольных и исследуемых группах. В контрольных группах количество CD11b не отличалось статистически после инкубации клеток крови с агонистами TLR (ЛПC, R848, ПГН). Напротив, в группах часто болеющих детей уровни индуцированной продукции CD11b отличались в зависимости от лигандов, и самое низкое количество CD11b наблюдалось после инкубации клеток крови с R848.

Таким образом, исследование влияния активирующих фракторов на количество интегрина CD11b на поверхности гранулоцитов показало, что уровень прироста CD11b после активации не зависит от возраста. В группах часто болеющих детей был обнаружен достоверно сниженный уровень прироста CD11b на гранулоцитах после активации TLR7/8, по сравнению с контрольными группами соответствующего возраста. Такая сниженная презентация молекул адгезии на поверхности гранулоцитов в ответ на стимуляцию TLR7/8 может препятствовать миграции этих клеток в места инфицирования и способствовать повышенной чувствительности к вирусным инфекциям и возникновению бактериальных осложнений.

Ключевые слова: TOLL-подобные рецепторы (TLR), гранулоциты, CD11b молекула адгезии.

Одержано: 17.02.2016

ISSN 1996-4536 (print) • ISSN 2311-0783 (on-line) • Біологічні Студії / Studia Biologica • 2016 • Том 10/№1 • С. 37-44 